\title{
Pengaruh Pemberian Jus Buah Pir (Pyrus Communis) terhadap Pembersihan Stain Ekstrinsik pada Resin Komposit
}

\author{
${ }^{1}$ Didiet S. Dendhana \\ ${ }^{2}$ Pemsi M. Wowor \\ ${ }^{3}$ Michael A. Leman \\ ${ }^{1}$ Program Studi Pendidikan Dokter Gigi Fakultas Kedokteran \\ ${ }^{2}$ Bagian Farmakologi dan Terapi Fakultas Kedokteran \\ ${ }^{3}$ Bagian Konservasi Gigi Program Studi Pendidikan Dokter Gigi Fakultas Kedokteran \\ Universitas Sam Ratulangi Manado \\ Email: didietstondd@gmail.com
}

\begin{abstract}
Tooth discoloration such as staining could possibly affect the condition of restorative treatment on the teeth caused by extrinsic and intrinsic factors. Bleaching could provide a solution to color changing problem of composite filling. Hydrogen peroxide $\left(\mathrm{H}_{2} \mathrm{O}_{2}\right)$, the most common chemical agent to perform bleaching, is found naturally in pear fruit; therefore, it could be an alternative treatment to reduce stain of composite filling. This study was aimed to find out the stain removal effect of blended pear fruit on composite filling. This is a laboratory experimental study with a pre-post control group design. Total samples were 20 pieces of circular composites with $5 \mathrm{~mm}$ in diameter and $2 \mathrm{~mm}$ in thickness. The samples were submerged in coffee extract for 10 days to create visible extrinsic staining at their surfaces, and then the discoloration was measured with spectrophotometer. After that, the samples were divided into two groups with ten samples each: group A, submerged in coffee extract and group B submerged in blended pear juice for seven days. After the submerging procedure performed, all samples of group B were measured again with spectrophotometer. The results showed that in group B there was a significant effect on stain removal of composite resin ( $p$ $<0.05)$. Conclusion: Blended pear fruit had stain removal effect in composite filling.
\end{abstract}

Keywords: pear juice, extrinsic stain, composite resin.

\begin{abstract}
Abstrak: Perubahan warna gigi berupa stain dapat memengaruhi kondisi restorasi dalam rongga mulut yang disebabkan oleh faktor ekstrinsik dan intrinsik. Bleaching dapat dilakukan untuk menangani masalah perubahan warna resin komposit. Salah satu bahan bleaching yang sering digunakan di bidang kedokteran gigi ialah hidrogen peroksida $\left(\mathrm{H}_{2} \mathrm{O}_{2}\right)$. Senyawa ini terkandung dalam buah pir yang dapat digunakan sebagai perawatan alternatif untuk mengurangi stain pada resin komposit. Penelitian ini bertujuan untuk mengetahui pengaruh pemberian jus buah pir terhadap pembersihan stain ektrinsik pada resin komposit. Jenis penelitian ialah eksperimental laboratorium dengan pre and post control group design. Jumlah sampel penelitian ialah 20 resin komposit yang dibentuk dengan diameter $5 \mathrm{~mm}$ dan tebal 2 $\mathrm{mm}$. Sampel direndam dalam larutan kopi selama 10 hari untuk melihat adanya stain ekstrinsik pada permukaan sampel resin komposit, kemudian dilakukan pengukuran perubahan warna dengan spektrofotometer. Setelah itu sampel dibagi atas dua kelompok masing-masih 10 buah sampel: kelompok A untuk perendaman dalam larutan kopi dan kelompok B untuk perendaman dalam jus buah pir selama tujuh hari kemudian sampel kelompok B dilakukan pengukuran kembali dengan spektrofotometer. Hasil penelitian menunjukkan terdapat pengaruh bermakna $(\mathrm{p}<0,05)$ terhadap pembersihan stain ekstrinsik pada resin komposit pada kelompok B. Simpulan: Pemberian jus buah pir dapat membersihkan stain ektrinsik pada resin komposit
\end{abstract}

Kata kunci: jus buah pir, stain ekstrinsik, resin komposit 
Bidang kedokteran gigi berkembang pesat dalam segi cakupan pengobatan yang meluas, salah satunya yakni adanya inovasi dalam pemilihan metode pengobatan penyakit-penyakit yang muncul dalam rongga mulut. Hal ini menyebabkan masyarakat tidak hanya mempertimbangkan kesembuhan penyakit-penyakit tersebut, tetapi juga dari sisi estetik untuk memperbaiki kesehatan gigi dan mulut secara keseluruhan. Salah satu gangguan pada fungsi estetik gigi-geligi yakni adanya perubahan warna (staining) yang dapat memengaruhi gigi secara individual maupun keseluruhan gigi-geligi di dalam rongga mulut. ${ }^{1,2}$

Perubahan warna berupa stain juga dapat memengaruhi kondisi restoratif yang terdapat di dalam rongga mulut, seperti yang terjadi pada gigi dengan tambalan sewarna gigi asli atau tambalan komposit. Saat ini, resin komposit merupakan bahan yang sering digunakan untuk penambalan gigi-geligi anterior karena manipulasi bahan yang mudah dan memiliki pilihan warna yang hampir serupa dengan warna gigi. ${ }^{3}$ Perubahan warna dapat terjadi pada tumpatan komposit yang disebabkan oleh beberapa faktor di antaranya kandungan makanan, minuman, dan rokok yang dikonsumsi secara berlebihan, yang dapat meninggalkan stain pada permukaan gigi maupun permukaan tumpatan komposit. Konsumsi minuman kopi secara berlebihan merupakan salah satu penyebab ekstrinsik munculnya stain. Penelitian yang dilakukan oleh Putri et al. ${ }^{4}$ di Denpasar menunjukkan bahwa stain dapat muncul pada permukaan tumpatan komposit dengan perendaman dalam larutan kopi selama tujuh hari.

Salah satu upaya mengurangi stain, yaitu dengan pemutihan gigi (bleaching). Proses ini umumnya dilakukan menggunakan senyawa seperti hidrogen peroksida dengan mekanisme kerja yakni mengoksidasi tubuli dentin, sehingga warna permukaan gigi menjadi lebih cerah. ${ }^{5}$

Buah pir (Pyrus communis) telah lama dikenal dan mudah dijumpai di berbagai toko buah dan pasar swalayan. Hasil penelitian menggunakan ekstrak buah pir sebagai bleaching agent yang dilakukan oleh Syaefah di Yogyakarta secara in-vitro pada gigi permanen menunjukkan adanya hasil bermakna antara lama perendaman dengan perubahan warna pada gigi permanen setelah direndam dengan ekstrak buah pir, meskipun hasilnya tidak sebanding dengan bahan pemutih kimiawi yang ada di pasaran. ${ }^{6}$ Penelitian serupa yang dilakukan oleh Shicha ${ }^{7}$ dengan metode penyikatan menggunakan pasta ekstrak buah pir pada gigi tiruan dan plat resin aklirik menunjukkan bahwa ekstrak buah pir efektif terhadap penghilangan stain ekstrinsik.

\section{METODE PENELITIAN}

Jenis penelitian ini ialah eksperimental dengan pre and post control group design. Penelitian dilaksanakan di Laboratorium Kimia FMIPA Universitas Sam Ratulangi Manado pada bulan Desember 2016-Juni 2017. Sampel penelitian berupa resin komposit jenis nanofiller dengan diameter 5 $\mathrm{mm}$ dan tebal $2 \mathrm{~mm}$ sebanyak 20 buah yang dibagi atas kelompok kontrol (10 buah) dan kelompok perlakuan (10 buah).

Bahan-bahan yang digunakan yaitu jus buah pir, etanol 96\%, resin komposit jenis nanofiller merk 3M (A3), kopi Kapal Api, dan air minum kemasan. Alat-alat yang digunakan yaitu cetakan resin komposit, light cured LA500, glass plate, wadah, pinset, timbangan, plastic instrument, blender, tissue, masker, dan libra S12UV/ Visible spectrophotometer Biochrom.

Sampel dibuat dalam bentuk tablet kecil sebanyak 20 buah dengan ukuran diameter $5 \mathrm{~mm}$ dan tebal $2 \mathrm{~mm}$ dengan cetakan sedotan plastik yang diletakan di atas glass plate. Resin komposit dimasukkan menggunakan plastic instrument ke dalam cetakan sedotan sampai memenuhi seluruh cetakan dan dilakukan penyinaran dengan light cured selama 20 detik dan resin komposit yang telah mengeras dikeluarkan dari cetakan. Air panas dituangkan ke dalam gelas sebanyak 100 ml kemudian dimasukkan dua sendok teh bubuk kopi (Arabica) murni dan diaduk. Larutan tersebut dibiarkan hingga sesuai dengan suhu ruangan. Sebanyak 100gr buah pir segar disiapkan dan dicuci sampai 
bersih kemudian diolah menjadi jus menggunakan blender.

Resin komposit berjumlah 20 buah d dimasukan pada larutan etanol $96 \%$ sebagai pelarut organik kemudian etanol $96 \%$ tersebut diletakkan pada spektrofotometer untuk pengukuran data warna awal sampel dan hasil pengukuran dicatat.

Sampel kemudian direndam di dalam larutan kopi yang sudah disiapkan sebelumnya selama 10 hari dihitung sejak pengukuran warna awal sampel dengan spektrofotometer. Setelah 10 hari sampel dikeluarkan dari dalam larutan kopi kemudian dipisahkan ke dalam dua kelompok masing-masing berisi 10 buah: kelompok A untuk perendaman di larutan kopi dan kelompok B untuk perendaman di dalam jus buah pir.

Sampel kelompok sampel dimasukkan ke dalam larutan etanol $96 \%$ kemudian larutan etanol $96 \%$ tersebut dimasukkan ke dalam spektrofotometer untuk diukur perubahan warna setelah perendaman dalam larutan kopi dan hasil pengukuran dicatat. Sampel kelompok B masih direndam dalam jus buah pir selama tujuh hari dihitung sejak awal pemindahan sampel dari larutan kopi kemudian sampel dimasukkan ke dalam etanol 96\%, selanjutnya larutan etanol tersebut diletakkan di spektrofotometer untuk mengetahui perubahan warna pada sampel.

\section{HASIL PENELITIAN}

\section{Hasil Pengukuran Sampel}

Pada hasil pengukuran warna sampel yang dilakukan sebelum sampel direndam dalam larutan kopi, didapatkan nilai rerata kecerahan sampel sebesar 2,16 yang merupakan nilai awal sampel (Tabel 1). Selanjutnya sampel direndam dalam larutan kopi selama 10 hari lalu dipisahkan menjadi dua kelompok yaitu kelompok control (A) dan kelompok intervensi (B).

Tabel 2 memperlihatkan selisih nilai kecerahan pada kelompok kontrol yang dihasilkan panjang gelombang 645 dengan panjang gelombang 663. Terdapat perbedaan nilai kecerahan pada setiap sampel. Dua dari 10 sampel dengan nilai selisih paling rendah dengan nilai kecerahan 0,3 dan satu dari 10 sampel dengan nilai selisih paling tinggi dengan nilai kecerahan 0,8 hampir mendekati angka satu pada nilai kecerahannya, kemudian diambil reata dari setiap pengukuran sampel. Nilai rerata kecerahan sampel setelah direndam dalam kopi menunjukkan adanya penurunan nilai kecerahan pada setiap sampel yang diukur menggunakan spektrofotometer.

Tabel 1. Pengukuran awal nilai kecerahan sampel resin komposit

\begin{tabular}{cccc}
\hline Sampel & PG 645 & PG 663 & PG 645-663 \\
\hline $\mathbf{1}$ & 0,0961 & 0,0745 & 0,0216 \\
$\mathbf{2}$ & 0,0961 & 0,0745 & 0,0216 \\
$\mathbf{3}$ & 0,0961 & 0,0745 & 0,0216 \\
$\mathbf{4}$ & 0,0961 & 0,0745 & 0,0216 \\
$\mathbf{5}$ & 0,0961 & 0,0745 & 0,0216 \\
$\mathbf{6}$ & 0,0961 & 0,0745 & 0,0216 \\
$\mathbf{7}$ & 0,0961 & 0,0745 & 0,0216 \\
$\mathbf{8}$ & 0,0961 & 0,0745 & 0,0216 \\
$\mathbf{9}$ & 0,0961 & 0,0745 & 0,0216 \\
$\mathbf{1 0}$ & 0,0961 & 0,0745 & 0,0216 \\
$\mathbf{1 1}$ & 0,0961 & 0,0745 & 0,0216 \\
$\mathbf{1 2}$ & 0,0961 & 0,0745 & 0,0216 \\
$\mathbf{1 3}$ & 0,0961 & 0,0745 & 0,0216 \\
$\mathbf{1 4}$ & 0,0961 & 0,0745 & 0,0216 \\
$\mathbf{1 5}$ & 0,0961 & 0,0745 & 0,0216 \\
$\mathbf{1 6}$ & 0,0961 & 0,0745 & 0,0216 \\
$\mathbf{1 7}$ & 0,0961 & 0,0745 & 0,0216 \\
$\mathbf{1 8}$ & 0,0961 & 0,0745 & 0,0216 \\
$\mathbf{1 9}$ & 0,0961 & 0,0745 & 0,0216 \\
$\mathbf{2 0}$ & 0,0961 & 0,0745 & 0,0216 \\
Hasil & & & 2,16 \\
\hline
\end{tabular}

Tabel 2. Nilai kecerahan kelompok kontrol

\begin{tabular}{ccccc}
\hline Sampel & $\begin{array}{c}\text { PG } \\
\mathbf{6 4 5}\end{array}$ & $\begin{array}{c}\text { PG } \\
\mathbf{6 6 3}\end{array}$ & $\begin{array}{c}\text { PG5 } \\
\mathbf{6 4 5 6 3}\end{array}$ & Hasil \\
\hline $\mathbf{1}$ & 0,049 & 0,044 & 0,005 & 0,5 \\
$\mathbf{2}$ & 0,049 & 0,046 & 0,003 & 0,3 \\
$\mathbf{3}$ & 0,050 & 0,045 & 0,005 & 0,5 \\
$\mathbf{4}$ & 0,052 & 0,044 & 0,008 & 0,8 \\
$\mathbf{5}$ & 0,051 & 0,046 & 0,005 & 0,5 \\
$\mathbf{6}$ & 0,049 & 0,044 & 0,005 & 0,5 \\
$\mathbf{7}$ & 0,050 & 0,045 & 0,005 & 0,5 \\
$\mathbf{8}$ & 0,049 & 0,046 & 0,003 & 0,3 \\
$\mathbf{9}$ & 0,051 & 0,045 & 0,006 & 0,6 \\
$\mathbf{1 0}$ & 0,050 & 0,044 & 0,006 & 0,6 \\
Hasil rerata nilai kecerahan & & 0,51 \\
\hline
\end{tabular}


Tabel 3 menunjukkan selisih nilai kecerahan pada kelompok intervensi yang dihasilkan panjang gelombang 645 dengan panjang gelombang 663, terdapat perbedaan nilai kecerahan pada setiap sampel. Dua dari 10 sampel dengan nilai selisih paling rendah dengan nilai kecerahan 1,4 dan dua dari 10 sampel dengan nilai selisih paling tinggi dengan nilai kecerahan 1,8 hampir mendekati angka dua pada nilai kecerahannya, kemudian diambil rata-rata dari setiap pengukuran sampel. Nilai rerata kecerahan sampel setelah direndam dalam jus buah pir selama tujuh hari menunjukan adanya peningkatan nilai kecerahan pada setiap sampel yang diukur menggunakan spektrofotometer.

Tabel 3. Nilai kecerahan kelompok intervensi

\begin{tabular}{ccccc}
\hline Sampel & $\begin{array}{c}\text { PG } \\
\mathbf{6 4 5}\end{array}$ & $\begin{array}{c}\text { PG } \\
\mathbf{6 6 3}\end{array}$ & $\begin{array}{c}\text { PG 645- } \\
\mathbf{6 6 3}\end{array}$ & Hasil \\
\hline $\mathbf{1}$ & 0,074 & 0,056 & 0,018 & 1,8 \\
$\mathbf{2}$ & 0,083 & 0,067 & 0,016 & 1,6 \\
$\mathbf{3}$ & 0,073 & 0,055 & 0,018 & 1,8 \\
$\mathbf{4}$ & 0,082 & 0,065 & 0,017 & 1,7 \\
$\mathbf{5}$ & 0,079 & 0,065 & 0,014 & 1,4 \\
$\mathbf{6}$ & 0,071 & 0,057 & 0,014 & 1,4 \\
$\mathbf{7}$ & 0,068 & 0,053 & 0,015 & 1,5 \\
$\mathbf{8}$ & 0,073 & 0,057 & 0,016 & 1,6 \\
$\mathbf{9}$ & 0,069 & 0,051 & 0,018 & 1,8 \\
$\mathbf{1 0}$ & 0,071 & 0,056 & 0,015 & 1,5 \\
Hasil rerata nilai kecerahan & 1,61 \\
\hline \multicolumn{5}{c}{}
\end{tabular}

Dari hasil pengukuran rearata nilai kecerahan kelompok intervensi yang berjumlah 10 sampel didapatkan nilai selisih yang dihasilkan panjang gelombang 645 dengan panjang gelombang 663, terdapat perbedaan nilai kecerahan pada setiap sampel. Dua dari 10 sampel dengan nilai selisih paling rendah dengan nilai kecerahan 1,4 dan dua dari 10 sampel dengan nilai selisih paling tinggi dengan nilai kecerahan 1,8 hampir mendekati angka dua pada nilai kecerahannya, kemudian diambil rerata dari setiap pengukuran sampel. Nilai rerata kecerahan sampel setelah direndam dalam jus buah pir selama tujuh hari menunjukkan adanya peningkatan nilai kecerahan pada setiap sampel yang diukur menggunakan spektrofotometer.

\section{Analisis Data}

Uji normalitas dilakukan untuk mengetahui normal atau tidaknya distribusi dari masing-masing data pada sampel. Pada penelitian ini uji normalitas yang digunakan ialah uji Shapiro Wilk dan diperoleh data terdistribusi normal ( $\mathrm{p}>0,05)$ (Tabel 4).

Tabel 4. Uji normalitas data

\begin{tabular}{ll}
\hline \multicolumn{1}{c}{ Perlakuan sampel } & Sig \\
\hline $\begin{array}{l}\text { Perendaman dalam kopi } \\
\begin{array}{l}\text { Perendaman dalam jus } \\
\text { buah pir }\end{array}\end{array}$ & 0,119 \\
\hline
\end{tabular}

Uji $\mathrm{t}$ berpasangan dilakukan untuk mengetahui adanya pengaruh jus buah pir terhadap pembersihan stain ekstrinsik pada resin komposit antara kedua kelompok dan didapatkan nilai sig 0,00 yang menunjukkan adanya pengaruh bermakna $(\mathrm{p}<0,05)$ setelah pemberian jus buah pir terhadap pembersihan stain ekstrinsik pada resin komposit.

\section{BAHASAN}

Berdasarkan penelitian yang telah dilakukan, diperoleh hasil perendaman sampel resin komposit dalam jus buah pir selama tujuh hari menunjukan adanya pengaruh bermakna terhadap pembersihan stain ekstrinsik pada resin komposit. Hal ini dapat dilihat dari hasil pengukuran spektrofotometer yang menunjukkan terjadinya peningkatan nilai kecerahan pada sampel yang direndam dalam jus buah pir. Hasil penelitian ini sejalan dengan penelitian yang dilakukan oleh Syaefah ${ }^{6}$ walaupun dengan metode yang berbeda yang melibatkan perendaman gigi permanen dalam ekstrak buah pir selama 24 jam, 48 jam, dan 92 jam untuk melihat perubahan kecerahan yang terjadi pada sampel setelah direndam dalam larutan teh hitam. Hasil penelitian tersebut menunjukkan adanya pengaruh terhadap tingkat kecerahan warna gigi setelah direndam dalam ekstrak buah pir, meskipun hasilnya tidak sebanding dengan bahan pemutih kimiawi yang ada di pasaran. 
Penelitian terhadap kemampuan $\mathrm{H}_{2} \mathrm{O}_{2}$ dalam buah pir (Pyrus communis) terhadap pembersihan stain ekstrinsik pada bahan resin juga telah dilakukan sebelumnya oleh Shicha ${ }^{7}$ yang melibatkan bahan resin berupa gigi artifisial dan plat resin akrilik yang sebelumnya telah direndam dalam larutan teh selama 6 hari dan kemudian disikat dengan tiga jenis pasta; salah satunya pasta ekstrak buah pir. Setelah penyikatan, dilakukan pengolahan data untuk menentukan intensitas kecerahan sampel. Hasil penelitian menunjukkan bahwa terdapat pengaruh bermakna dari penyikatan dengan pasta ekstrak buah pir terhadap stain ekstrinsik pada gigi artifisial dan plat resin akrilik.

\section{SIMPULAN}

Dari hasil penelitian dapat disimpulkan bahwa terdapat pengaruh bermakna dari pemberian jus buah pir (Pyrus communis) terhadap pembersihan stain ekstrinsik pada sampel resin komposit.

\section{SARAN}

Kiranya praktisi dapat mengembangkan penelitian ini sebagai bahan acuan untuk penelitian selanjutnya mengenai buah pir sebagai bleaching agent alternatif dalam pengembangan ilmu pengetahuan.

\section{DAFTAR PUSTAKA}

1. Albers HF. Tooth Colored Restoratives: Principle and Techniques (9th ed). London: BC Decker Inc, 2002; p. 8.

2. Putri MH, Herijulianti E, Nurjanah N. Ilmu Pencegahan Penyakit Jaringan Keras dan Jaringan Pendukung Gigi. Jakarta: Penerbit Buku Kedokteran EGC, 2012; p. 77.

3. Phillips AKJ. Buku Ajar Ilmu Bahan Kedokteran Gigi (10th ed). Jakarta: Penerbit Buku Kedokteran EGC, 2003; p. 227-45.

4. Adiguna NMGP. Pengaruh konsentrasi kopi robusta sebagai bahan perendaman pada perubahan warna resin komposit nanohibrida [Skripsi]. Denpasar: Universitas Mahasaraswati; 2014.

5. Wang XJ. Structural aspects of bleaching and fluoride application on dental enamel. Hamburg: Poliklinik für Kieferorthopadie, 2008, p. 17.

6. Syaefah N. Pengaruh lama perendaman ekstrak buah pir (Pyrus communis) terhadap pemutihan gigi (Bleaching) secara in-vitro pada gigi permanen [Karya Tulis Ilmiah]. Yogyakarta: Universitas Muhammadiyah Yogykarta; 2012.

7. Shicha SA. Pengaruh pasta ekstrak pir (Pyrus communis) terhadap penghilangan extrinsic stain pada permukaan gigi, gigi artifisial, dan plat resin akrilik. [Skripsi]. Yogyakarta: Universitas Gadjah Mada; 2015. 